\title{
Instrument Development for Measuring the Acceptance of UC\&C: A Content Validity Study
}

\author{
Emy Salfarina Alias ${ }^{1}$, Muriati Mukhtar ${ }^{2}$, Ruzzakiah Jenal ${ }^{3}$ \\ Faculty of Information Science and Technology \\ Universiti Kebangsaan Malaysia (UKM), Bangi, Selangor
}

\begin{abstract}
Studies on the acceptance of Unified Communications and Collaboration (UC\&C) tools such as instant messaging and video conferencing have been around for some time. Adoption and acceptance of $\mathrm{UC \& C}$ tools and services has boosted productivity and improved communications by integrating voice, video and data into one platform. UC\&C also allows collaboration by enabling users to interact with each other in different media. However, their acceptance rate by individual in developing nations has been low. It is hypothesized that the factors that contribute to acceptance are developed based on two underlying theories. The first is that of diffusion of innovation and the other is that of service dominant logic. Items is constructed based on eight constructs which are relative advantage, compatibility, ease of use, trialability, observability, improved service, value co-creation capacity, and coordination efficiency. In order to validate the items, content validity ratios are calculated on a set of questionnaire. The ratios will determine which items should be included or removed from the questionnaire. The paper concludes with a discussion on the implications of the findings from the experts' evaluation and also from the content validity ratios. The new items are used in designing the survey instrument to measure the acceptance of UC\&C.
\end{abstract}

Keywords-Acceptance model; content validity; diffusion of innovation; service science; unified communications and collaboration

\section{INTRODUCTION}

Unified Communication and Collaboration (UC\&C) which has been introduced in over a decade is a popular new technology used by organizations for communications purposes. Previous studies [1]-[3] state that UC\&C services are used in organizations to ease user involvement in communication activities. However, organizations still lack knowledge about the availability of UC\&C in providing effective communications [4], [5]. Pérez et al. [3] also have pointed out that practitioners and scholars need to develop more understanding of the factors which can contribute or hampers successful adoption of UC\&C.

According to Amily and Zaidi [6], the marketing strategies of communication technology should be focused on understanding the needs, trends and lifestyles of their potential users. Besides, the involvement of customer in the technologybased service is important for successful service delivery [7]. Therefore, there is a need to discover factors that influence the acceptance of UC\&C in organizations. In a previous study by Emy Salfarina Alias et al. [8], eight constructs that influence the acceptance of UC\&C services has been identified. Items derived from these constructs are then developed into an assessment instrument for UC\&C services users. Prior to administering the instrument, it has to go through a validation process. There are various ways to do this, one of which is via feedbacks from expert panels [9]. Accordingly, in this paper, the content validity of the assessment instrument of the UC\&C services is evaluated by using by Lawshe's technique.

This paper is structured as follows: In Section II, a discussion of the related works is given. Section III describes the research method followed by results and analysis in Section IV. Section V discusses the findings and the limitations of the study. Section VI concludes the paper with suggestions for future research.

\section{RELATED WORKS}

Content validity refers to the ability of selected survey instruments to adequately reflect the characteristics of the measured constructs [10]. Also, the purpose of content validity is to determine the extent to which dimensions and concept elements are clearly explained [11]. Item verification function, on the other hand, examines whether it is sufficient to measure each construct [12]. According to Saunders et al. [13] comments and suggestions from experts would help establish content validity in order to make necessary amendments before pilot testing.

The development of the instrument needs to go through the validity process of the content to ensure that constructed constructions are legitimate, clear and reflect its contents [14]. Content validity can be implemented qualitatively or quantitatively as shown in Table I.

According to Nor'ashikin Ali et al. [17], qualitative analysis is difficult to interpret and the results obtained are less accurate because the questionnaire usually involves a large number of items. Meanwhile, Allahyari et al. [14] believes quantitative analysis is a better solution for content validity. Quantitative methods using Lawshe techniques are selected for this study because of its practical method. Based on the research conducted by Tojib and Sugianto [18], the content validity ratio (CVR) calculated using Lawshe techniques is more practical, convenient and saves time especially during the evaluation process. The CVR uses binomial distribution and also prepares tables to determine the values to be followed in calculations based on the number of experts involved [19]. In addition, CVR calculations are also suitable for use in studies involving a small number of experts. 
TABLE I. CONTENT VALIDITY METHOD

\begin{tabular}{|c|c|c|}
\hline No. & Method & Description \\
\hline \multicolumn{3}{|c|}{ Qualitative } \\
\hline 1. & $\begin{array}{l}\text { Intensive literature } \\
\text { review }\end{array}$ & $\begin{array}{l}\text { Construct is measured by adapting questions } \\
\text { from previous researchers. This method only } \\
\text { refers to existing instruments, without going } \\
\text { through an evaluation process by an expert } \\
\text { panel. }\end{array}$ \\
\hline 2 & $\begin{array}{l}\text { Content validity } \\
\text { assessment by the } \\
\text { expert panel }\end{array}$ & $\begin{array}{l}\text { Constructs are measured based on expert } \\
\text { panel evaluation analysis through comments, } \\
\text { ideas, and feedback submitted. }\end{array}$ \\
\hline \multicolumn{3}{|c|}{ Quantitative } \\
\hline 1. & $\begin{array}{l}\text { Content validity ratio } \\
\text { (CVR) } \\
{[15]}\end{array}$ & $\begin{array}{l}\text { This method involves questionnaires } \\
\text { assessed by a group of experts using a three } \\
\text { points Likert scale to assess every construct. } \\
\text { Comment space is provided so that expert } \\
\text { panels can provide their additional views. } \\
\text { The number of experts is not determined and } \\
\text { usually depends on the suitability of the } \\
\text { study. The CVR calculation is based on } \\
\text { acceptance criteria set by Lawshe [15]. }\end{array}$ \\
\hline 2 & $\begin{array}{l}\text { Content validity ratio } \\
\text { (CVR) } \\
{[14]}\end{array}$ & $\begin{array}{l}\text { This method is similar with the Lawshe } \\
\text { method; it used a five Likert scale to assess } \\
\text { each construct. The CVR calculation is } \\
\text { based on acceptance criteria set by Allahyari } \\
\text { et al. [14]. }\end{array}$ \\
\hline 3 & $\begin{array}{l}\text { Content validity index } \\
\text { (CVI) } \\
{[16]}\end{array}$ & $\begin{array}{l}\text { This method involves the assessment of } \\
\text { constructs by experts panel based on the } \\
\text { scale of four which is " } 1=\text { irrelevant", " } 2= \\
\text { somewhat relevant", " } 3=\text { relevant ", and" } 4 \\
\text { = very relevant ". The number of expert } \\
\text { panels is between three and ten. }\end{array}$ \\
\hline
\end{tabular}

The content validity index (CVI) is not considered in this study because the scale 4 is not universal and can cause doubt [18]. According to Nor'ashikin Ali et al. [17] CVI uses normal distribution that can cause inconsistencies and is less suitable for a small number of expert panels. Hence, this paper discusses step by step the process involved in the development of the instrument and subsequently validates the content by adapting the steps proposed by Nor'ashikin Ali et al. [17] using the CVR technique introduced by Lawshe [15].

\section{RESEARCH METHOD}

\section{A. Research Design}

Questionnaire is an effective data collection tool or mechanism for researchers when conducting a survey [20]. The data collected must be up-to-date, uniform and adhere to prescribed sampling procedures [11]. Prior to the questionnaire development process, a thorough understanding of the important concepts in the study must be acquired via an in depth literature review [22].

The development of a questionnaire in this study adapted the procedure introduced by Mackenzie et al. [23] which originally contained 10 steps, but summarized by combining several steps into only six steps to suit the three key processes conceptualization, development process, and validity as shown in Fig. 1.
This study uses a structured and closed questionnaire that respondents are required to read questions/statements and choose the answers available. This type of questionnaire is chosen because it is easy to administer because the questions and answers are available to enable respondents to respond easily and accurately. The questionnaire should facilitate the respondents to answer questions. The approach to the questionnaire of this study is fundamental to the guidelines proposed by Creswell [24] which is from public-shaped questions to special forms, does not involve sensitive issues and not burden respondents. The physical design of a good question can help to increase the understanding of the respondents and then increase the rate of return and the accuracy of the answers. As suggested by Fallis [25], question designs need to be clear, easy to read and not confusing format. The questionnaire administration method should be established early either by correspondence, email, telephone or face-to-face interview.

\section{B. Research Procedure}

The research procedure can be broken into six steps. The steps are explained as follows

Step 1: Develop a conceptual definition of the constructs.

Previous study has identified the conceptual framework in evaluating UC\&C services through literature review. The conceptual model was developed for measuring the factors that could influence the acceptance of UC\&C [8]. The framework has identified eight factors that could contribute to the acceptance of UC\&C services. They are relative advantage, compatibility, ease of use, trialability, observability, improved service, value co-created capacity and coordination efficiency. All of these factors have been identified through the literature by combining two theories which are diffusion of innovation theory (DOI) and service dominant logic (SDL) from service science. DOI is chosen because UC\&C services is seen to be an evolving technology that is progressing to meet current demand in communication and collaboration. It is thus interesting to view UC\&C as a diffusion, hence the use of DOI. Complementing the use of DOI, SDL has been chosen because, SDL encompass the concepts of value in use and value co-creation which are crucial concepts that enable users to extract the value from UC\&C services. Using these two theories as the basis, a conceptual framework for the acceptance of UC\&C was developed. The framework is made up of eight factors or constructs. Each of the constructs are then elaborated into items. Here, a total of 49 items were identified.

Generating concept definitions for the involved constructs is important to ensure that constructs can represent the concepts being studied and the constructs are unique [26]. Development of the questionnaire can be done through the reuse of existing constructs obtained from past studies, but amendments need to be made to conform to the context of the study [21], [27]. According to Kitchenham and Pfleeger [28], the advantages of reapplying existing constructs are: (i) existing constructs have undergone validity and reliability tests; and (ii) comparison of findings of current and past studies can be done. Table II shows the list of definitions for the eight constructs involved in the study. 


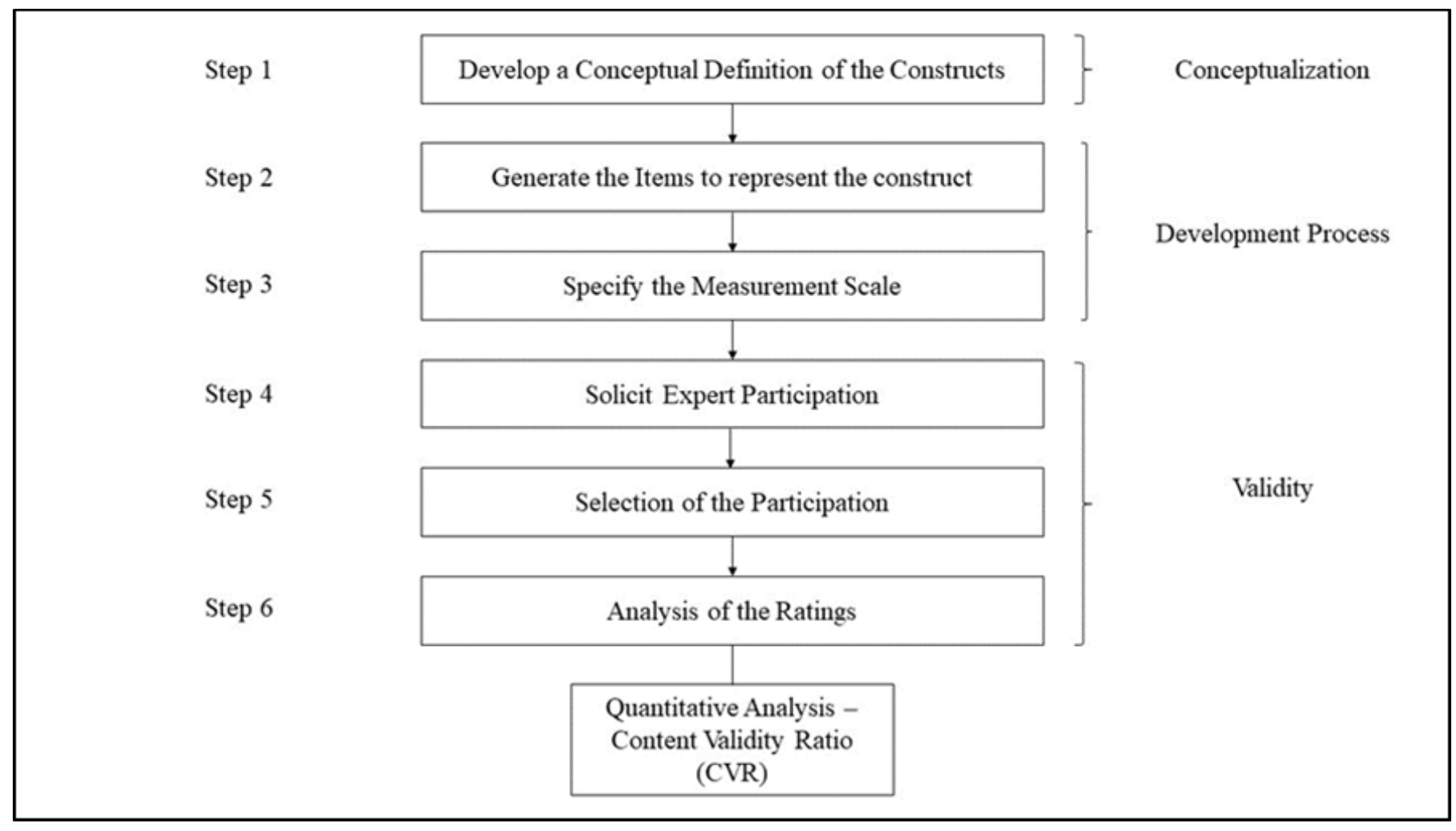

Fig. 1. Process of Instrument Development.

TABLE II. THE DEFINITION OF CONSTRUCT

\begin{tabular}{|c|c|c|c|}
\hline No. & Factor & Definition & Source \\
\hline 1. & $\begin{array}{l}\text { Relative } \\
\text { advantage }\end{array}$ & $\begin{array}{l}\text { The degree to which an } \\
\text { innovation is } \\
\text { Perceived as better than the idea } \\
\text { it supersedes. }\end{array}$ & [29] \\
\hline 2. & Compatible & $\begin{array}{l}\text { The degree to which an } \\
\text { innovation is perceived } \\
\text { As being consistent with the } \\
\text { existing values, past experiences, } \\
\text { and needs of potential adopters. }\end{array}$ & [29] \\
\hline 3. & Ease of use & $\begin{array}{l}\text { The degree to which an } \\
\text { innovation is perceived as } \\
\text { Easy to understand and use. }\end{array}$ & [29] \\
\hline 4. & Trialability & $\begin{array}{l}\text { The degree to which an } \\
\text { innovation may be experimented } \\
\text { with on a limited basis. }\end{array}$ & [29] \\
\hline 5. & Observability & $\begin{array}{l}\text { The degree to which the results } \\
\text { of an innovation } \\
\text { Are visible to others. }\end{array}$ & [29] \\
\hline 6 & $\begin{array}{l}\text { Improved } \\
\text { Service }\end{array}$ & $\begin{array}{l}\text { The degree to which service is } \\
\text { improved or new service is } \\
\text { created from the introduced } \\
\text { innovation. }\end{array}$ & [8] \\
\hline 7. & $\begin{array}{l}\text { Value Co- } \\
\text { Created } \\
\text { Capacity }\end{array}$ & $\begin{array}{l}\text { The degree to which value co- } \\
\text { creation is enabled or allowed in } \\
\text { the organizations. }\end{array}$ & [8] \\
\hline 8. & $\begin{array}{l}\text { Coordination } \\
\text { Efficiency }\end{array}$ & $\begin{array}{l}\text { The degree to which the } \\
\text { institutions or institutional } \\
\text { arrangements coordinates value } \\
\text { co-creation in the organizations. }\end{array}$ & [8] \\
\hline
\end{tabular}

Step 2: Generate the Items to Represent the Construct

Podsakoff et al. [30] asserts that the selection of indicators is necessarily based on indicators with high weighting value in a construct because, low weighting value indicates that the construct is not correctly measured (no validity exists). Hair et al. [31] states that in order to provide stability to the constructs, each construct should have at least three indicators. Overall, this study involved 49 indicators (initial recommendation) to measure eight constructs as shown in Table III.

Step 3: Specify the Measurement Scale

There are various opinions on the number of optimal measurement scales such as even numbers $(2,4,6,8$ or 10) or odd $(3,5,7$ or 9$)$. For an odd numbered scale, the numbers in the middle represent the neutral, uncertain, unknown or irrelevant choices. Whereas the even numbered scale shows the respondents are forced to choose the answer either positive or negative [28]. An odd numbered scale (scale 3 and 5) can match the model accurately over the even numbered scale. Hence, the survey questionnaire uses three Likert scale which are (1) not necessary, (2) useful but not essential and (3) essential.

\section{Step 4: Solicit Expert Participation}

Experts expressing the desire to participate were sent a package that contains: a) cover letter, b) a content review form. Participants are given 20 days to complete the form and send it back to the researcher. The cover letter explains the rationale for conducting the research and also indicates the confidentiality of the responses. 
TABLE III. The CONSTRUCTION OF MEASUREMENT INDICATOR

\begin{tabular}{|c|c|c|c|}
\hline Construct & Code Item & In the UC\&C Context & $\begin{array}{l}\text { Adaptation } \\
\text { from }\end{array}$ \\
\hline $\begin{array}{l}\text { Relative } \\
\text { advantage }\end{array}$ & RA1 - RA6 & $\begin{array}{l}\text { Describes acceptance of the } \\
\text { benefits offered by UC\&C } \\
\text { services among employees } \\
\text { in your organization. }\end{array}$ & {$[32]-[35]$} \\
\hline Compatibility & $\begin{array}{l}\text { COM1 - } \\
\text { COM6 }\end{array}$ & $\begin{array}{l}\text { Describes your acceptance } \\
\text { of the suitability of UC\&C } \\
\text { services within your } \\
\text { organization. }\end{array}$ & {$[32]-[35]$} \\
\hline Ease of use & EU1 - EU4 & $\begin{array}{l}\text { Describe your acceptance of } \\
\text { UC\&C service capabilities } \\
\text { that are easy to use and } \\
\text { understand. }\end{array}$ & {$[32]-[34]$} \\
\hline Trialability & $\begin{array}{l}\text { TRIAL1 - } \\
\text { TRIAL7 }\end{array}$ & $\begin{array}{l}\text { Describing your acceptance } \\
\text { with UC\&C service trials } \\
\text { helps users become more } \\
\text { knowledgeable about their } \\
\text { use. }\end{array}$ & $\begin{array}{l}{[33],[35]-} \\
{[37]}\end{array}$ \\
\hline Observability & $\mathrm{OB} 1-\mathrm{OB} 2$ & $\begin{array}{l}\text { Describes your acceptance } \\
\text { of UC \& C services that } \\
\text { emphasize the provision of } \\
\text { experience to users. }\end{array}$ & [35], [38] \\
\hline $\begin{array}{l}\text { Improved } \\
\text { service }\end{array}$ & IS1 - IS5 & $\begin{array}{l}\text { Describes the perception of } \\
\text { UC\&C service could } \\
\text { improve and combine the } \\
\text { services to create new } \\
\text { service. }\end{array}$ & [39] \\
\hline $\begin{array}{l}\text { Value co- } \\
\text { created } \\
\text { capacity }\end{array}$ & $\begin{array}{l}\text { VCC1 - } \\
\text { VCC5 }\end{array}$ & $\begin{array}{l}\text { Describes the perception of } \\
\text { the organization is allowed } \\
\text { value co-creation to extract } \\
\text { the value of UC\&C. }\end{array}$ & {$[40]-[43]$} \\
\hline $\begin{array}{l}\text { Coordination } \\
\text { efficiency }\end{array}$ & $\begin{array}{l}\text { COOR1 - } \\
\text { COOR5 }\end{array}$ & $\begin{array}{l}\text { Describes the perception of } \\
\text { UC\&C services are allowed } \\
\text { your organization to } \\
\text { coordinate value co- } \\
\text { creation. }\end{array}$ & $\begin{array}{l}{[34],[37],} \\
{[42],[44]}\end{array}$ \\
\hline $\begin{array}{l}\text { Acceptance of } \\
\text { UC\&C }\end{array}$ & $\begin{array}{l}\text { ACC1 - } \\
\text { ACC6 }\end{array}$ & $\begin{array}{l}\text { Describes the perception of } \\
\text { the UC\&C adoption in your } \\
\text { organizations. }\end{array}$ & [45], [46] \\
\hline
\end{tabular}

Invitation to the panel of experts for the purpose of obtaining consent engagement in content validity sessions is performed individually via official email and telephone. Email is accompanied by an official letter. Once the expert agrees to be involved, a date is set for the interview sessions. The validity session content by all experts takes two to three weeks to be completed and transcribed.

\section{Step 5: Selection of the Participation}

1) Expert Panel Selection: Nor'ashikin Ali et al. [17] recommends the selected panel of experts to be involved and who are experienced in the same domain and have expertise in the development of the instrument (whether from academic or professional). There are some opinions in determining the number of experts. Lawshe [15] suggested that the panel of experts be composed of at least four people while Allahyari et al. [14] suggested 8 to 16 people. Nor'ashikin Ali et al. [17] on the contrary think that the expert panel should consist of 2 to 20 people.
In this study, seven experts were identified for content validity sessions. The selected specialist consists of academics, experienced professionals in the implementation of UC\&C and consultants from industry sectors and Public Sector agencies. Table IV indicates the profiles of experts. Selection criteria are based on panel experience and involvement in relevant areas and fulfilling one or more of the following criteria:

- Knowledgeable and experienced in the field of service science.

- Experienced in the development and implementation of $\mathrm{UC} \& \mathrm{C}$ in the private or public sector.

- Knowledgeable in theory, statistical or construct measurement.

TABLE IV. PROFILES OF EXPERTS

\begin{tabular}{|l|l|l|l|}
\hline Expert ID & Organization & $\begin{array}{l}\text { Year of } \\
\text { experience }\end{array}$ & Expertise/Experience \\
\hline Expert 1 & Industry & 6 & UC\&C \\
\hline Expert 2 & Industry & 8 & UC\&C \\
\hline Expert 3 & Industry & 2 and half & UC\&C \\
\hline Expert 4 & Academic & 10 & Service Science \\
\hline Expert 5 & Academic & 21 & Service Science \\
\hline Expert 6 & Academic & 10 & Service Science \\
\hline Expert 7 & Academic & 14 & Service Science \\
\hline
\end{tabular}

IV. RESUlt AND ANALYSIS

Validity means the extent to which the measurements (indicators) used are able to represent the concept correctly and also the extent to which the selected indicators correspond to the construct [47]. Content validity is also known as expert confirmation as it is performed by a group of professional panels or experts in the related field [21]. The validity study described in this paper adapts the process introduced by Lawshe [15] and is also used in the study of [14], [17], [48]. It is based on quantitative methods using Likert 3 scale which is (1) not necessary, (2) useful but not essential and (3) essential. Expert panel is required to evaluate and validate the significance of the indicators based these given scales of 1 to 3 .

Based on the feedback from the expert panel, the consensus among experts is measured by the calculation of CVR [15], which is analyzed using Microsoft Excel software. Table $\mathrm{V}$ shows that the minimum Lawshe's CVR value. While, in this study, the calculation of CVR is adapted from Nor'ashikin Ali et al. [17], the answers "2" and "3" are considered relevant while the answers "1" are irrelevant. The formula used is:

CVR value $=(2 \mathrm{Ne} / \mathrm{N})-1$

- $\mathrm{Ne}=$ The number of experts who gave the relevant answer " $2=$ Agree" and " $3=$ Strongly Agree"

- $\mathrm{N}=$ Total number of experts 
This equation is described below:

- If everyone on the panel of experts indicated the answer " 3 = essential", then, the CVR value is 1.00 (all agreed).

- If more than half ( $>50 \%$ ), but less than everyone $(<100 \%)$ on the panel of experts indicated the answer "3 = essential", then, the CVR value is positive, ranging between 0.00 and 0.99 .

- If less than half $(<50 \%)$ of the panel of experts indicated the answer " $3=$ essential", then, the CVR value is negative:

TABLE V. The Minimum Lawshe’s CVR VALUe

\begin{tabular}{|l|l|}
\hline Number of Panelist & Minimum Acceptable CVR Value \\
\hline 5 & 0.99 \\
\hline 6 & 0.99 \\
\hline 7 & $\mathbf{0 . 9 9}$ \\
\hline 8 & 0.78 \\
\hline 9 & 0.75 \\
\hline 10 & 0.62 \\
\hline 15 & 0.49 \\
\hline 20 & 0.42 \\
\hline 25 & 0.37 \\
\hline 30 & 0.33 \\
\hline
\end{tabular}

Table VI shows the final results of CVR calculations. Based on the calculation, there are two indicators that are rejected because they returned the value of 0.71 . Hence, 47 indicators will be included in the final questionnaire.

TABLE VI. CVR CALCULATION RESULT FOR EACH INDICATOR

\begin{tabular}{|c|c|c|c|c|}
\hline Construct & Code & Total essential & CVR & Result \\
\hline \multirow{6}{*}{$\begin{array}{l}\text { Relative } \\
\text { advantage }\end{array}$} & RA1 & 7 & 1.00 & Accepted \\
\hline & RA2 & 7 & 1.00 & Accepted \\
\hline & RA3 & 7 & 1.00 & Accepted \\
\hline & RA4 & 7 & 1.00 & Accepted \\
\hline & RA5 & 7 & 1.00 & Accepted \\
\hline & RA6 & 6 & 0.71 & Rejected \\
\hline \multirow{6}{*}{ Compatibility } & COM1 & 7 & 1.00 & Accepted \\
\hline & COM2 & 7 & 1.00 & Accepted \\
\hline & COM3 & 7 & 1.00 & Accepted \\
\hline & COM4 & 7 & 1.00 & Accepted \\
\hline & COM5 & 7 & 1.00 & Accepted \\
\hline & COM6 & 7 & 1.00 & Accepted \\
\hline \multirow{3}{*}{ Ease of use } & EU1 & 7 & 1.00 & Accepted \\
\hline & EU2 & 7 & 1.00 & Accepted \\
\hline & EU3 & 7 & 1.00 & Accepted \\
\hline
\end{tabular}

\begin{tabular}{|c|c|c|c|c|}
\hline & EU4 & 7 & 1.00 & Accepted \\
\hline \multirow{7}{*}{ Trialability } & TRIAL1 & 7 & 1.00 & Accepted \\
\hline & TRIAL2 & 7 & 1.00 & Accepted \\
\hline & TRIAL3 & 7 & 1.00 & Accepted \\
\hline & TRIAL4 & 7 & 1.00 & Accepted \\
\hline & TRIAL5 & 7 & 1.00 & Accepted \\
\hline & TRIAL6 & 7 & 1.00 & Accepted \\
\hline & TRIAL7 & 7 & 1.00 & Accepted \\
\hline \multirow{5}{*}{ Observability } & OB1 & 7 & 1.00 & Accepted \\
\hline & OB2 & 7 & 1.00 & Accepted \\
\hline & OB3 & 7 & 1.00 & Accepted \\
\hline & OB4 & 7 & 1.00 & Accepted \\
\hline & OB5 & 7 & 1.00 & Accepted \\
\hline \multirow{5}{*}{$\begin{array}{l}\text { Improved } \\
\text { service }\end{array}$} & IS1 & 7 & 1.00 & Accepted \\
\hline & IS2 & 7 & 1.00 & Accepted \\
\hline & IS3 & 7 & 1.00 & Accepted \\
\hline & IS4 & 7 & 1.00 & Accepted \\
\hline & IS5 & 7 & 1.00 & Accepted \\
\hline \multirow{5}{*}{$\begin{array}{l}\text { Value co- } \\
\text { created } \\
\text { capacity }\end{array}$} & $\mathrm{VCC} 1$ & 7 & 1.00 & Accepted \\
\hline & $\mathrm{VCC} 2$ & 7 & 1.00 & Accepted \\
\hline & VCC3 & 7 & 1.00 & Accepted \\
\hline & $\mathrm{VCC} 4$ & 7 & 1.00 & Accepted \\
\hline & VCC5 & 7 & 1.00 & Accepted \\
\hline \multirow{5}{*}{$\begin{array}{l}\text { Coordination } \\
\text { efficiency }\end{array}$} & COOR1 & 7 & 1.00 & Accepted \\
\hline & COOR2 & 7 & 1.00 & Accepted \\
\hline & COOR3 & 6 & 0.71 & Rejected \\
\hline & COOR4 & 7 & 1.00 & Accepted \\
\hline & COOR5 & 7 & 1.00 & Accepted \\
\hline \multirow{6}{*}{$\begin{array}{l}\text { Acceptance of } \\
\text { UC\&C }\end{array}$} & $\mathrm{ACC} 1$ & 7 & 1.00 & Accepted \\
\hline & $\mathrm{ACC} 2$ & 7 & 1.00 & Accepted \\
\hline & ACC3 & 7 & 1.00 & Accepted \\
\hline & ACC4 & 7 & 1.00 & Accepted \\
\hline & ACC5 & 7 & 1.00 & Accepted \\
\hline & ACC6 & 7 & 1.00 & Accepted \\
\hline
\end{tabular}

\section{DISCUSSION}

The process of developing a detailed instrument (step by step) can be improved by understanding of the researcher and can be used as a guide to build a questionnaire instrument. It can also serve as a guide for future researchers in their specific fields. The development of a complete and orderly instrument can improve the quality of research management while producing good and reliable results. Thus, weak instruments are not capable of generating high quality outputs, thus 
generating dubious findings. The valid and reliable questionnaire can be used to assess the level of acceptance of UC\&C services in organizations. The results from the panel of experts yielded the following results. A total of 47 items fulfilled the condition of CVR. After the CVR calculations were done, two items were marked up for deletion as they failed to meet the set criteria. Item RA6 was rejected because one of the experts commented that the item has the same meaning with item RA3. Item COOR3 was rejected because it is irrelevant based on the comment from an IT service provider expert. The item is related to the provision of UC\&C training for users. Since not all respondents for a future survey will come from IT related fields, the item is still considered important, and it is possible, after further investigation to still retain the item code COOR3. Besides this, three experts suggested minor revisions regarding the clarity or wording of the items, and those revisions were incorporated into the instrument.

Even though the study had carefully selected its experts, more insights can be obtained and the study can be further improved by including more experts from more diverse fields.

\section{CONCLUSION}

This paper has highlighted a method that can be used to validate the contents of a survey instrument that was constructed to investigate the factors that drives the adoption of UC\&C. A total of 49 items were evaluated which resulted in two items being rejected. In this study, it is shown that the CVR approach is able to differentiate the opinion of experts clearly and easily. All the 47 items that were refined would proceed to a pilot testing by distributing the questionnaire to the targeted respondents. Through the pilot study, the items will then be subjected to more statistical tests in order to confirm that they are reliable and valid to be used in the main study.

\section{ACKNOWLEDGMENT}

The researchers would like to thank the expert panels for participating in this study. They would also like to thank UKM Zamalah Research Scheme and FRGS/2/2014/ICT01/UKM/02/ research grant.

\section{REFERENCES}

[1] Bolton, M. Murray, and J. Fluker, "Transforming the Workplace: Unified Communications \& Collaboration Usage Patterns in a Large Automotive Manufacturer," in 50th Hawaii International Conference on System Sciences, 2017, pp. 5470-5479.

[2] C. Meske, T. Kissmer, and S. Stieglitz, "Global adoption of unified communication technologies as part of digital transformation in organizations: A cross-cultural perspective," in Multikonferenz Wirtschaftsinformatik (MKWI 2018), 2018.

[3] J. Pérez, M. Murray, J. Fluker, D. Fluker, and Z. Bailes, "Connectivity and Continuity: New Fronts in the Platform War," Communications of the Association for Information Systems, vol. 40, no. 1, pp. 167-180, 2017.

[4] J. Palonka and T. Porębska-Miąc, "Cloud Computing and Mobility as the Main Trends in Unified Communications," Studia Ekonomiczne, vol. 188, no. 119-134, 2014.

[5] J. Yahaya, M. M. Basir, and A. Deraman, "Unified Communication and Collaboration Model for Virtual Distributed Team Work: A Study in Malaysia," International Journal of Software Engineering and Its Applications, vol. 9, no. 2, pp. 125-142, 2015.
[6] F. Amily and A. G. @ M. Zaidi, "Unified communication: it's all between you and me," Business Strategy Series, vol. 13, no. 4, pp. 168$172,2012$.

[7] S. H. M. Handrich, "Adoption of technology-based services: the role of customers' willingness to co-create," Journal of Service Management, vol. 26, no. 1, 2015.

[8] Emy Salfarina Alias, Muriati Mukhtar, and Ruzzakiah Jenal, “Adoption of Unified Communications and Collaboration from the Perspective of Diffusion of Innovation and Service-Dominant Logic: A Preliminary View," International Journal on Advanced Science Engineering Information Technology, vol. 8, no. 5, pp. 1882-1889, 2018.

[9] V. K. Shrotryia and U. Dhanda, "Content Validity of Assessment Instrument for Employee Engagement," SAGE Open, 2019.

[10] M. H. Imani-Nasab, B. Yazdizadeh, M. Salehi, H. Seyedin, and R. Majdzadeh, "Validity and reliability of the Evidence Utilisation in Policymaking Measurement Tool (EUPMT)," Health Research Policy and Systems, vol. 15, no. 1, pp. 1-11, 2017.

[11] U. Sekaran, Research Methods for Business, 4th ed. New York: John Wiley \& Sons, Inc, 2003.

[12] N. K. Agarwal, "Verifying survey items for construct validity: A twostage sorting procedure for questionnaire design in information behavior research," in Proceedings of the ASIST, 2011.

[13] M. Saunders, P. Lewis, and A. Thornhill, Research Methods for Business Students, 5th ed. Edinburgh Gate: Pearson Education Limited, 2009.

[14] T. Allahyari, N. H. Rangi, Y. Khosravi, and F. Zayeri, "Development and evaluation of a new questionnaire for rating of cognitive failures at work," International Journal of Occupational Hygiene, vol. 3, no. 1, pp. 6-11, 2011.

[15] C. H. Lawshe, "A quantitative approach to content validity," Personnel Psychology, vol. 28, no. 4, pp. 563-575, 1975.

[16] M. R. Lynn, "Determination and Quantificatiom of Content Validity," Nursing Research, vol. 35, no. 6. pp. 382-385, 1986.

[17] Nor'ashikin Ali, A. Tretiakov, and D. Whiddett, "A Content Validity Study for a Knowledge Management Systems Success Model in Healthcare A Content Validity Study for a Knowledge Management Systems Success Model in Healthcare," Jitta, vol. 15, no. 2, pp. 21-36, 2014.

[18] D. R. Tojib and L. F. Sugianto, "Content Validity of Instruments in IS Research," Journal of Information Technology Theory and Application (JITTA), vol. 8, no. 3, pp. 31-56, 2006.

[19] R. S. Rai, "Innovating in Practice: A Practice-Theoretical Exploration of Discontinuous Service Innovations," 2016.

[20] M. Wook, Z. M. Yusof, and M. Z. A. Nazri, "Educational data mining acceptance among undergraduate students," Education and Information Technologies, vol. 22, no. 3, pp. 1195-1216, 2016.

[21] Muslihah Wook, "Model Penerimaan Perlombongan Data Pendidikan Dalam Kalangan Pelajar Universiti Awam Di Malaysia," Universiti Kebangsaan Malaysia, 2017.

[22] A. A. Aziz, Z. M. Yusof, U. A. Mokhtar, and D. I. Jambari, "Penerimagunaan Sistem Pengurusan Dokumen dan Rekod Elektronik: Protokol Pembangunan Instrumen dan Kesahan Kandungan Menggunakan Nilai Ketetapan Kandungan,” Jurnal Pengurusan, vol. 53, 2018.

[23] S. B. Mackenzie, P. M. Podsakoff, and N. P. Podsakoff, "Construct Measurement and Validation Procedures in MIS and Behavioral Research : Integrating New and Existing Techniques," MIS Quarterly, vol. 35, no. 2, pp. 293-334, 2011.

[24] J. W. Creswell, Research Design Qualitative, Quantitative and Mixed Methods Approaches, 4th ed. 2014.

[25] A. . Fallis, Case Study Methodology in Business Research, vol. 53, no. 9. 2013.

[26] S. B. Mackenzie and P. M. Podsakoff, "Common Method Bias in Marketing: Causes , Mechanisms, and Procedural Remedies," Journal of Retailing, vol. 88, no. 4, pp. 542-555, 2012.

[27] U. Sekaran and R. Bougie, Research Methods for Business: A Skill Building Approach, 5th ed. Wiley, 2010. 
[28] B. A. Kitchenham and S. L. Pfleeger, "Principles of Survey Research Part 3: Constructing a Survey Instrument," vol. 27, no. 2, pp. 20-24, 2002.

[29] E. M. Rogers, Diffusion of Innovation, 4th ed. 1995.

[30] P. M. Podsakoff, S. B. Mackenzie, and N. P. Podsakoff, "Sources of Method Bias in Social Science Research and Recommendations on How to Control It," 2012.

[31] J. F. Hair, M. Sarstedt, T. M. Pieper, and C. M. Ringle, "The Use of Partial Least Squares Structural Equation Modeling in Strategic Management Research: A Review of Past Practices and Recommendations for Future Applications," Long Range Planning, vol. 45, no. 5-6, pp. 320-340, 2012.

[32] I. M. Al-Jabri and M. S. Sohail, "Mobile banking adoption: application of diffusion of innovation theory," Journal of Electronic Commerce Research, vol. 13, no. 4, pp. 379-391, 2012.

[33] A. Peslak, W. Ceccucci, and P. Sendall, "An Empirical Study of Social Networking Behavior Using Diffusion of Innovation Theory," Conference on Information Systems Applied Research, 2010.

[34] L. Carter and F. Bélanger, "The utilization of e-government services: Citizen trust, innovation and acceptance factors," Information Systems Journal, vol. 15, no. 1, pp. 5-25, 2005.

[35] T. J. Ntemana and W. Olatokun, "Analyzing the Influence of Diffusion of Innovation Attributes on Lecturers' Attitudes Toward Information and Communication Technologies," Journal on Humans in ICT Environments, vol. 8, no. 2, pp. 179-197, 2012.

[36] E. Mao, M. Srite, J. B. Thatcher, and O. Yaprak, “A research model for mobile phone service behaviors: Empirical validation in the U.S. and Turkey," Journal of Global Information Technology Management, vol. 8, no. 4, pp. 7-28, 2005.

[37] Hasimi Sallehudin, "Factors Influencing the Assimilation of Cloud Computing Services and Its Effect on Operational Effectiveness in the Malaysian Public Sector," University Malaysia Kelantan, 2017.

[38] P. Verdergem and L. De Marez, "Rethinking Determinants of ICT Acceptance: Towards An Integrated and Comprehensive Overview,"
Technovation, vol. 31, no. 8, pp. 411-423, 2011.

[39] A. Ordanini and A. Parasuraman, "Service innovation viewed through a service-dominant logic lens: A conceptual framework and empirical analysis," Journal of Service Research, vol. 14, no. 1, pp. 3-23, 2011.

[40] C. Morosan and A. DeFranco, "Co-creating value in hotels using mobile devices: A conceptual model with empirical validation," International Journal of Hospitality Management, vol. 52, pp. 131-142, 2016.

[41] I. O. Karpen, L. L. Bove, B. A. Lukas, and M. J. Zyphur, "Servicedominant orientation: Measurement and impact on performance outcomes," Journal of Retailing, vol. 91, no. 1, pp. 89-108, 2014.

[42] K. T. Yip, "The Attributes of Value Co-creation in Service and its Impact on Customers Willingness to Pay. Observations from Three Service Industries," University of Exeter, 2011.

[43] K. R. Ranjan and S. Read, "Value co-creation: concept and measurement," Journal of the Academy of Marketing Science, vol. 44, no. 3, pp. 290-315, 2016.

[44] L. Gao and X. Bai, "A unified perspective on the factors influencing consumer acceptance of internet of things technology," Asia Pacific Journal of Marketing and Logistics, vol. 26, no. 2, pp. 211-231, 2014.

[45] H. Ahmadi, M. Nilashi, L. Shahmoradi, and O. Ibrahim, "Computers in Human Behavior Hospital Information System adoption: Expert perspectives on an adoption framework for Malaysian public hospitals," Computers in Human Behavior, 2016.

[46] B. Pinnock, "Environmental and Organisational Drivers Influencing the Adoption of Unified Communications Technology in South Africa," University of Cape Town, 2011.

[47] J. F. Hair, C. M. Ringle, and M. Sarstedt, "Editorial Partial Least Squares Structural Equation Modeling: Rigorous Applications, Better Results and Higher Acceptance," Long Range Planning, vol. 46, no. 12, pp. 1-12, 2013.

[48] W. A. Z. Wan Ahmad, M. Mukhtar, and Y. Yahya, "Validating the Contents of a Social Content Management Framework," in The 2017 6th International Conference on Electrical Engineering and Informatics (ICEEI), 2017. 